\title{
Peran dan Fungsi E-Bussiness Dalam Bisnis Digital
}

Loise yolanda Veronika

Faculty of computer Universitas Mitra Indonesia

loiseyolanda.student@umitra.ac.id

1. Jelaskan Proses dalam E-Bisnis berkaitan secara menyeluruh dengan proses bisnis lainnya, seperti:

- Value Chain: pembelian secara elektronik (Electronic Purchasing), serangkaian kegiatan bisnis yang mana pada setiap tahapan atau langkahnya mampu meningkatkan nilai atau pemanfaatan pada barang atau jasa yang diproduksi.

- Manajemen Rantai Pasok (Supply Chain Management), adalah sebuah system terkoodinasi yang terdiri atas organisasi, sumber daya manusia,aktifitas,informasi dan sumber-sumber daya lainnya.

- Pemrosesan order elektronik, adalah sebuah kegiatan pembelian barang secara online dan otomatis

- Penanganan dan pelayanan kepada pelanggan, adalah suatu proses pemenuhan kebutuhan melalui aktifitas orang lain secara langsung.

- Kerja sama dengan mitra bisnis, adalah sebuah strategi dalan sebuah bisnis sebagai upaya menjalankan suatu usaha.

2. Jelaskan dalam kegiatan e-bisnis, ada lima kemungkinan bentuk hubungan bisnis berdasarkan transaksinya, yaitu:

- Business to Business (perdagangan Antar pelaku usaha bisnis), adalah jenis bisnis yang digunakan antar perusahaan dengan perusahaan lainnya baik itu pada perusahaan yang bergerak pada industry yang sama ataupun yang berbeda dan kegiatan transaksinya dilakukan melalui internet.

- Business to Consumer (perdagangan antar pelaku usaha bisnis dengan konsumen), adalah jenis perdagangan yang dilakukan secara eletronik oleh suatu perusahaan yang kemudian menjual produknya secara langsung ke para pembeli

- Consumer to Consumer (perdagangan antar konsumen yang satu dengan konsumen yang lain), mereka yang terlibat dalam jenis e-bussiness ini adalah pelanggan dan mereka akan menjualnya lagi ke pelanggan lain

- Consumer to Business (Perdagangan antar konsumen dengan pelaku bisnis atau perusahaan), adalah suatu jenis bisnis dimana konsumen atau pelanggan akan memberitahukan apa yang mereka perlukan. 
- Intrabusiness e-business (perdagangan dalam lingkup intranet perusahaan yang melibatkan pertukaran barang, jasa, dan informasi), adalah perdagangan dalam lingkup intranet perusahaan yang melibatkan pertukaran barang, jasa dan informasi. 